\title{
Comparative Study of Balanced Nutrition Knowledge of Health Care in the Village and Sub-district of Kabila District Bone Bolango Regency
}

\author{
Hartati Inaku \\ Bakti Nusantara College of Health Sciences, Gorontalo, Indonesia
}

\begin{abstract}
Health cadres have responsibility for the local community and leaders appointed by the health center. They are expected to be able to carry out the instructions given by the supervisor in the work relationship of the health team. This article aims to examine the Comparative Study of Balanced Nutrition Knowledge of Health Cadres in the Village and Sub-district of Kabila District, Bone Bolango Regency. The type of research used in this research is comparative quantitative research with a cross-sectional study approach. The population in this study were all health cadres registered in the villages and sub-districts of Kabila District Bone Bolango Regency, as many as 72 health cadres. The sample size in the study was determined based on the Slovin method which was 42 samples. The results of the research were 17 health cadres in the village had sufficient knowledge of balanced nutrition (81.0\%). Meanwhile, a small proportion of them had less knowledge of balanced nutrition, namely 1 person (4.8\%). Most of the health cadres in the Sub-districts have sufficient knowledge of balanced nutrition, as many as 15 people (71.4\%). Meanwhile, a small proportion of them had less knowledge of balanced nutrition, namely 2 people $(9.5 \%)$. There is no difference in the level of knowledge of balanced nutrition among health cadres in the village and health cadres in the sub-district with a $\mathrm{p}$ value of 0.140 .
\end{abstract}

Keywords: Nutrition Knowledge, Balanced Nutrition, Health Cadres

Received : October 22, 2020

Received in Revised: October 31, 2020

Accepted: November 1, 2020

\section{Introduction}

The activeness of health cadres as implementers of service activities at the village and subdistrict level is the key to successful services at UKBM (Community-Based Health Efforts) because health cadres are the liaison between the program and the community, health cadres are community members who work voluntarily, and are able to move the community. The function of health cadres for UKBM facilities is classified as very large, starting at the stage of preparation, implementation and being a liaison for institutions that support the implementation, as planning implementers, and supervisors as well as trainers in motivating the community. It is hoped that the ability of cadres to communicate information can educate the public to always apply the principles of healthy living by always consuming balanced and diverse nutrition (Yulisa 2018).

Cadres must have the ability to communicate educational information (IEC) to optimize the delivery of balanced nutrition messages to the community in an appropriate and communitybased manner. Without good skills and knowledge in understanding the concept of balanced nutrition, there will be concerns that the message of balanced nutrition cannot be delivered to the public. This can have an impact on the low level of public knowledge about nutrition, the low ability of the community to practice the principles of diverse and balanced nutritional consumption, and the low participation of the community in utilizing public health service 
facilities at the village and sub-district levels such as Posyandu (Integrated Service Post) and Poskesdes (Village Health Post) so that within a certain period of time it can have an impact on cases of nutritional problems, both nutritional problems caused by lack of macro nutrient intake and lack of micronutrient intake. Indicators to measure knowledge of balanced nutrition can refer to the four pillars of balanced nutrition and the basic message of balanced nutrition published by the Directorate General of Nutrition and Health Midwives for Ibnu and Children of the Ministry of Health in 2015.

Adistie et al. (2017) have examined the cadres' ability in implementing community nutrition improvement in nutrition management. The results showed that cadres had good knowledge of $39 \%$, cadres had sufficient knowledge of $54.2 \%$ and cadres had insufficient knowledge about management nutrition $6.8 \%$. The results of research by Hardiyani et al (2018) show that of the 46 health cadres who studied the knowledge of the application of balanced nutrition, $43.5 \%$ of health cadres had insufficient nutritional knowledge. The results of research by Shaluhiyah et al (2020) which looked at cadres' knowledge about nutrition for pregnant women showed that $10 \%$ of cadres did not know that exclusive breastfeeding was breastfeeding only for babies aged 0-6 months, there were 10\%, did not know about giving Fe tablets to pregnant women $23,3 \%$ and cadres do not know that carbohydrates and minerals are nutrients, there are 73.7.

The results of the recapitulation of nutrition program data in the Kabila District, Bone Bolango Regency based on the indicators contained in the Regulation of the Minister of Health of the Republic of Indonesia Number 2 of 2020 concerning Children's Anthropometric Standards show that "The data on cases of nutritional problems per May of 2020 are as follows: children are short and very stunting was 121 cases, underweight was 55 cases, and very underweight was 36 cases, malnutrition was 44 cases and malnutrition was 27 cases ". The data on the achievement of visits as of May 2020 shows that the level of community participation visiting the posyandu has only reached $78 \%$. If we look at the data on the percentage of nutrition cases based on the village and sub-district areas in Kabila District, it can be seen that as many as $53 \%$ of the cases of nutrition problems are at the village level while $47 \%$ of the cases of nutrition problems are at the sub-district level. Meanwhile, the level of community participation in visiting UKBM shows that the average level of community visits in the village is $74 \%$, while the average level of community visits in the sub-district is $68 \%$. This data shows that in terms of the number of cases, the geographic area of the village has a greater number of cases, while in terms of the level of community participation, the sub-district area has lower visit outcomes.

The results of interviews conducted by researchers to the nutrition manager at Kabila Health Center regarding a description of cadres' knowledge about the concept of balanced nutrition during nutrition training in 2019 showed that the results of the pre-test knowledge of cadres who were in the good category were $20 \%, 30 \%$ sufficient, and less. 50\%. Where most of the cadres still lack knowledge of the concept of balanced nutrition. After training on balanced nutrition, a post test was conducted to re-test the cadres' knowledge. The result is a good category of $60 \%$, just $25 \%$ and less $15 \%$. This shows that there has been an increase in cadres' knowledge about the concept of balanced nutrition. Although there are still $40 \%$ of cadres' knowledge level, they are still in the sufficient and insufficient categories. This impact may affect cadre services in managing UKBM.

Health cadres have responsibility for the local community and leaders appointed by the health center. It is possible that community health cadres work full time or part time in the field of health services, without being paid in money or other forms, from the local community or by 
the puskesmas (Community Health Center) (Hardiyanti \& Susilaningsih, 2017). The variety of types of food consumed is influenced by the quality or quality of nutrition and the completeness of nutrients. The more diverse the food is consumed, the easier it is for the body to obtain various other substances that are beneficial to health (Herforth \& Ahmed, 2015; Miller \& Cassady, 2015; Badrah et al., 2020).

Previously, it was explained that poor knowledge about balanced nutrition by health cadres will likely have implications for not delivering the message of balanced nutrition to the community which results in low public knowledge of nutrition, low community ability to practice the consumption of balanced and diverse nutrition and low community participation in utilize UKBM so that in a certain period of time it will have an impact on the occurrence of cases of nutrition and the low level of community participation in visiting UKBM both in villages and sub-districts. This article aims to examine the Comparative Study of Balanced Nutrition Knowledge of Health Cadres in the Village and sub-district of Kabila District, Bone Bolango Regency.

\section{Methods}

\section{Design and Type of Research}

The type of research used in this research is comparative quantitative research with a crosssectional study approach, where the researcher wants to study the difference in knowledge of balanced nutrition for health cadres in the village and sub-district of Kabila District, Bone Bolango Regency.

\section{Location and Time of Research}

The place for the research was carried out in the villages and sub-districts of Kabila District, Bone Bolango Regency. The time of research will be carried out from July to August 2020

\section{Population and Sample}

The population in this study were all health cadres registered in the villages and sub-districts of Kabila District Bone Bolango Regency, as many as 72 health cadres.

The sample size in the study was determined based on the Slovin method which was 42 samples. The sampling technique used was proportionate stratified random sampling, where the number of village and sub-district health cadres was proportionally divided so that each sample was 21 samples. The distribution of personnel at Kabila Health Center consists of 2 general practitioners, 1 dentist, 2 S1 Public Health, 15 midwives, 8 nurses, 2 nutritionists, 1 sanitarian, 6 administrative staff, and 19 contract workers person.

The number of samples in each village and sub-district can be seen in the table below: active cadres, willing to be sampled. Exclusion criteria are not willing to be respondents. For the number of cadres in sub-district, the proportional distribution model can only be done for 4 sub-district, and the value of the decimal numbers for each sub-district is rounded up and added to the number in one of the closest sub-district, Oluhuta sub-district. The instrument (tool) used to measure the Knowledge Level of Health Cadres is a questionnaire quoted from the attachment to the Kabila Health Center family health survey 2019.

\section{Results and Discussion}

Table 1. Distribution of Village Health Cadres by Age in the Work Area of Kabila Health Center, Bone Bolango Regency

\begin{tabular}{ccc}
\hline Age (Years) & Amount & Percentage $(\%)$ \\
\hline
\end{tabular}




\begin{tabular}{|c|c|c|}
\hline$<26$ & 2 & 9,5 \\
\hline $26-35$ & 5 & 23,8 \\
\hline $36-45$ & 8 & 38,1 \\
\hline $46-55$ & 4 & 19,0 \\
\hline $56-65$ & 2 & 9,5 \\
\hline Total & 21 & 100,0 \\
\hline
\end{tabular}

Table 1 shows that most of the health cadres in the village were aged 36 to 45 years, as many as 8 people (38.1\%). While a small proportion of them were $<26$ years old and 56 to 65 years old, namely 2 people each $(9,5 \%)$.

Table 2. Distribution of Village Health Cadres by Age in the Work Area of the Kabila Health Center, Bone Bolango Regency

\begin{tabular}{|c|c|c|}
\hline Age (Years) & Amount & Percentage $(\%)$ \\
\hline$<26$ & 1 & 4,8 \\
\hline $26-35$ & 1 & 4,8 \\
\hline $46-55$ & 17 & 81,0 \\
\hline $56-65$ & 1 & 4,8 \\
\hline$>65$ & 1 & 4,8 \\
\hline Total & 21 & 100,0 \\
\hline
\end{tabular}

Table 2 shows that most of the health cadres in the Sub-district were aged 46 to 55 years, as many as 17 people $(81.0 \%)$. While a small proportion of them were $<26$ years old, 26 to 35 years old, 56 to 65 years old and $>65$ years old, namely 1 person $(4.8 \%)$ respectively.

Table 3. Distribution of Village Health Cadres by Education in the Work Area of the Kabila Community Health Center, Bone Bolango Regency

\begin{tabular}{lcc}
\hline \multicolumn{1}{c}{ Education } & Amount & Percentage (\%) \\
\hline Elementary School & 3 & 14,3 \\
Junior School & 5 & 23,8 \\
High School & 12 & 57,1 \\
Diploma & 1 & 4,8 \\
\hline \multicolumn{1}{c}{ Total } & 21 & 100,0 \\
\hline
\end{tabular}

Table 3 shows that most of the health cadres in the village had high school education, namely 12 people (57.1\%). Meanwhile, a small proportion of them have a Diploma III education, namely 1 person $(4.8 \%)$.

Table 4. Distribution of Village Health Cadres by Education in the Work Area of Kabila Health Center, Bone Bolango Regency

\begin{tabular}{lcc}
\hline \multicolumn{1}{c}{ Education } & Amount & Percentage $(\%)$ \\
\hline Elementary School & 0 & 19,0 \\
Junior School & 4 & 81,0 \\
High School & 17 & 0 \\
Diploma & 0 & 0 \\
\hline \multicolumn{1}{c}{ Total } & 21 & 100,0 \\
\hline
\end{tabular}

Table 4 shows that most of the health cadres in the Sub-district had high school education, namely 17 people (81.0\%), compared to 4 people (19.0\%) with junior high school education. 
Table 5. Distribution of Village Health Cadres by Occupation in the Work Area of the Kabila Community Health Center, Bone Bolango Regency

\begin{tabular}{lcc}
\hline \multicolumn{1}{c}{ Employment } & Amount & Percentage (\%) \\
\hline Village officials & 1 & 4,8 \\
Housewife & 19 & 90,5 \\
Cadres & 1 & 4,8 \\
\hline \multicolumn{1}{c}{ Total } & 21 & 100,0 \\
\hline
\end{tabular}

Table 5 shows that most of the health cadres in the village are housewives, as many as 19 people $(90.5 \%)$. Meanwhile, a small proportion of them work as village officials and only as cadres, namely 1 person each $(4.8 \%)$.

Table 6. Distribution of Village Health Cadres by Occupation in the Work Area of the Kabila Health Center, Bone Bolango Regency

\begin{tabular}{lcc}
\hline \multicolumn{1}{c}{ Employment } & Amount & Percentage (\%) \\
\hline Honorary & 4 & 19,0 \\
Housewife & 16 & 76,2 \\
Cadres & 1 & 4,8 \\
\hline \multicolumn{1}{c}{ Total } & 21 & 100,0 \\
\hline
\end{tabular}

Table 6 shows that most of the health cadres in the Sub-districts are housewives, as many as 16 people (76.2\%). Meanwhile, a small proportion work as cadres, namely 1 person (4.8\%).

Table 7. Distribution of Village Health Cadres by Length of Becoming a Cadre in the Work Area of the Kabila Community Health Center, Bone Bolango Regency

\begin{tabular}{lrr}
\hline \multicolumn{1}{c}{ Period Becoming } & Amount & Percentage (\%) \\
Cadres & & 66,7 \\
\hline <6 Years & 14 & 4,8 \\
6 - 10 Years & 1 & 19,0 \\
11 - 15 Years & 4 & 4,8 \\
16 - 20 Years & 1 & 4,8 \\
> 20 Years & 1 & 100,0 \\
\hline \multicolumn{1}{c}{ Total } & 21 & \\
\hline
\end{tabular}

Table 7 shows that most of the health cadres in the village have been active as cadres for $<6$ years, as many as 14 people $(66.7 \%)$. Meanwhile, a small proportion of them have been active as cadres for 6 to 10 years, for 16 to 20 years and for $>20$ years, namely 1 person each $(4.8 \%)$.

Table 8. Distribution of Village Health Cadres by Length of Time as Cadres in the Work Area of the Kabila Community Health Center, Bone Bolango Regency

\begin{tabular}{lcc}
\hline \multicolumn{1}{c}{ Period Becoming } & Amount & Percentage (\%) \\
\hline Cadre & & 9,5 \\
6 - 10 Years & 2 & 28,6 \\
11 - 15 Years & 6 & 28,6 \\
16 - 20 Years & 6 & 33,3 \\
20 Years & 7 & 0 \\
\hline \multicolumn{1}{c}{ Total } & 0 & 100,0 \\
\hline
\end{tabular}


Table 8 shows that most of the health cadres in the Sub-district have been active as cadres for 16 to 20 years, as many as 7 people $(33.3 \%)$. While a small proportion of them have been active as cadres for $<6$ years, namely 2 people $(9.5 \%)$.

\section{Univariate Analysis}

Below can be seen the results of a univariate analysis of balanced nutrition knowledge of health cadres in villages and sub-districts of Kabila District, Bone Bolango Regency.

Table 9. Balanced Nutrition Knowledge of Health Cadres in Villages in the Work Area of the Kabila Community Health Center, Bone Bolango Regency

\begin{tabular}{lcc}
\hline Level of Knowledge & Amount & Percentage (\%) \\
\hline Good & 4 & 19,0 \\
Enough & 15 & 71,4 \\
Less & 2 & 9,5 \\
\hline \multicolumn{1}{c}{ Total } & 21 & 100,0 \\
\hline
\end{tabular}

Table 12 shows that most of the health cadres in the village have sufficient knowledge of balanced nutrition, namely 15 people (71.4\%). Meanwhile, a small proportion of them had less knowledge of balanced nutrition, namely 2 people $(9.5 \%)$.

Table 10. Balanced Nutrition Knowledge of Health Cadres in sub-district in the Work Area of Kabila Health Center, Bone Bolango Regency

\begin{tabular}{lcc}
\hline Level of Knowledge & Amount & Percentage (\%) \\
\hline Good & 3 & 14,3 \\
Enough & 17 & 81,0 \\
Less & 1 & 4,8 \\
\hline \multicolumn{1}{c}{ Total } & 21 & 100,0 \\
\hline
\end{tabular}

Table 13 shows that most of the health cadres in the Sub-district have sufficient knowledge of balanced nutrition, namely 17 people (81.0\%). Meanwhile, a small proportion of them had less knowledge of balanced nutrition, namely 1 person $(4.8 \%)$.

\section{Bivariate Analysis}

Below can be seen the results of the bivariate analysis of the Comparative Study of Balanced Nutrition Knowledge of Health Cadres in the Village and Sub-district of Kabila District, Bone Bolango Regency.

Table 11. Balanced Nutrition Knowledge of Health Cadres in Villages and Sub-districts in the Work Area of the Kabila Community Health Center, Bone Bolango Regency

\begin{tabular}{|c|c|c|c|c|}
\hline $\begin{array}{c}\text { Balanced Nutrition } \\
\text { Knowledge }\end{array}$ & Mean & T count & T Table & $\begin{array}{c}\text { Paired Sample } \\
\text { Test }\end{array}$ \\
\hline $\begin{array}{c}\text { Health Cadres in } \\
\text { the Village }\end{array}$ & 68,13 & \multirow{2}{*}{-1.538} & $\begin{array}{c}\text { Df } 20 \\
(2,086)\end{array}$ & 0,140 \\
\cline { 1 - 2 } $\begin{array}{c}\text { Health Cadre in } \\
\text { Sub-district }\end{array}$ & 71,39 & & & \\
\hline
\end{tabular}

Table 11 shows that the average knowledge score for health cadres in the village is 68.13 (sufficient category), and the average knowledge score for health cadres in the village is 71.39 (sufficient category). This shows that the average value of balanced nutritional knowledge between health cadres in the village and Sub-district is in the sufficient category, 
but there is a difference of 3.12 points. Where the mean value of knowledge of cadres in the Village is higher than the mean value of knowledge of cadres in the Village. The $t$ value shows the number -1.538 , where the value is lower than the table value seen from the 2sided test table with a value of $2.086(-1.538<2.086)$ with a significance value $(0.140>0.05)$. This means that there is no difference in the level of knowledge of balanced nutrition among health cadres in the village and health cadres in the village.

The results of the analysis have shown that there is no difference in the level of knowledge of balanced nutrition between health cadres in the village and health cadres in the sub-district with the $t$ value of -1.538 , which is lower than the table value seen from the 2-sided test table with a value of 2.086. (-1.538<2.086) with a significance value $(0.140>0.05)$. However, if observed based on the acquisition of the average value, it shows that there is a point difference of 3.12 points where health cadres in the Sub-district have a higher mean value.

If we look closely, based on the level of knowledge about balanced nutrition, health cadres show that the percentage level of knowledge on balanced nutrition of health cadres in the village is more in the sufficient category, namely $71.4 \%$, then in the good category is $19.0 \%$ and is in the poor category is as much as 9,5\%. When compared with the level of knowledge of balanced nutrition among health cadres in the Sub-district, it can be seen that the percentage of sufficient knowledge has a higher value, namely as much as $81.0 \%$ with a point difference of $9.6 \%$ (higher sub-district), good knowledge $14.3 \%$ with a difference. points $4,7 \%$ (higher village), as well as lack of nutrition knowledge as much as $4,8 \%$ with a point difference of 4,7 (higher village). After seeing the total average value, it shows that there is a difference of 3.12 points where the value of the level of knowledge of balanced nutrition among cadres in the village has a higher number. However, based on statistical studies, it has shown that there is no significant difference between knowledge of balanced nutrition among cadres in the village and knowledge of balanced nutrition among cadres in the village.

When viewed from the cross tabulation results between the education level of health cadres in the village with knowledge of balanced nutrition, it can be seen that 1 cadre with Diploma III education has good knowledge, 12 cadres with High School (SMA) 9 of whom have sufficient knowledge and 3 have good knowledge, 5 cadres with junior high school education 4 of them have sufficient knowledge and 1 is lacking, and 3 cadres with elementary education 2 of them have sufficient knowledge and 1 is lacking. The data shows that all insufficient knowledge is entirely distributed in Elementary School and Junior School (low education). If it is seen based on the length of activity as health cadres, it shows that cadres with low knowledge have been active as cadres who have only lasted $<6$ years. Meanwhile, cadres with good knowledge have a long time as cadres, namely 11 to 15 years and $>20$ years. There is 1 cadre with good knowledge with a working period of $<6$ years, but if seen from the education level of this cadre is a Diploma III bachelor. This means that in addition to tenure, the level of education also has an influence on the high understanding of cadres about balanced nutrition.

Meanwhile, if seen from the cross tabulation results between the education level of health cadres in the Sub-district with knowledge of balanced nutrition, it can be seen that 17 cadres with high school education (SMA) 14 of them have sufficient knowledge and 3 have good knowledge, and 4 cadres with junior high school education 3 of them have enough knowledge and 1 less. The data shows that 1 cadre with less knowledge has a junior high school education (low education). If it is seen based on the length of activity as health cadres, it shows that cadres with low knowledge have been active as cadres who have only lasted $<6$ 
years. Meanwhile, cadres with good knowledge have a long period of time as cadres, namely 11 to 15 years and 16 to 20 years.

The education level of health cadres has a positive correlation with cadres' knowledge of balanced nutrition. People with higher education tend to have good knowledge and have the ability to think more rationally (Kuklinski \& Quirk, 2000; Lauglo, 2013).

A mother (health cadre) with higher education tends to have sufficiently mature considerations in making a decision. Because all external input that comes in both formally and informally will be properly selected and have benefits for him and his family environment. Good knowledge about balanced nutrition possessed by everyone, including health cadres, will be able to be a factor in breaking the chain of nutrition problems at both the family and community levels. A person's education level will have an effect in responding to something that comes from outside. Highly educated people will provide a more rational response to the information that comes and reason to think about the extent to which they might gain from the idea. Mothers have a higher level of education, the easier it is to adopt information, the higher a person's education, the easier it will be to receive information.

The results of statistical analysis showing that there is no difference in knowledge of balanced nutrition between health cadres in villages and sub-districts are in line with the results of Yanti \& Hasballah's (2016) research which shows that there is no significant difference in the performance level of posyandu (Integrated Service Post) cadres between the two regions with a $\mathrm{p}$ value $>0.05$. . Previous data have illustrated that in addition to the length of time working as energy tends to affect cadres 'knowledge of balanced nutrition, formal education also affects, the higher the level of formal education, the better the cadres' knowledge of balanced nutrition. Because someone with a higher education level will find it much easier to capture the information conveyed by the message giver, both messages conveyed directly by officers, and messages obtained from information media both visual and audio-visual media. On the other hand, if it is seen from the long term of activity as a health cadre, it is possible that the longer the period of time as a cadre, the intensity of the guidance given by the officer in terms of training, technical guidance and other activities will be far more if compared with the period of activity as a possible cadre. not too long ago.

The Director General of Nutrition and KIA of the Ministry of Health of the Republic of Indonesia in 2015 in the Balanced Nutrition Guidelines book states that cadres must be able to convey messages to improve community nutrition. Cadres are expected to be able to guide the community, encourage, give advice, and provide convenience to target families in recognizing, preventing and overcoming nutritional problems they face and being able to choose and sort out good ways to consume balanced nutrition.

Yulisa (2018) explains that the activeness of health cadres as implementing service activities at the village and sub-district level is the key to the success of services at UKBM (Community-Based Health Efforts) because health cadres are the liaison between the program and the community, health cadres are community members who work voluntarily and able to move the community. The function of health cadres for UKBM facilities is very large, starting from the preparation stage, implementation and being a liaison with institutions that support the implementation, as executing planners, as supervisors and as instructors to motivate the community. The ability of cadres in communicating information is expected to be able to educate the public to always apply the principles of healthy living by always consuming balanced and diverse nutrition. 
As a fairly basic effort in strengthening the ability of cadres in delivering messages on balanced nutrition. So the delivery of balanced nutrition messages to the community by cadres really requires proper and community-based Education Information Communication (KIE) skills. Without good skills and knowledge in understanding the concept of balanced nutrition, there will be concerns that the message of balanced nutrition cannot be delivered to the public. This can have an impact on the low knowledge of the community about nutrition, the low ability of the community to practice the principle of diverse and balanced nutritional consumption, and the low participation of the community in utilizing public health service facilities at the village and sub-district levels such as posyandu (Integrated Service Post) and poskesdes (Village Health Post) so that within a certain period of time. can have an impact on the occurrence of cases of nutritional problems, both nutritional problems caused by lack of intake of macro nutrients and lack of intake of micronutrients.

\section{Conclusion}

Most of the health cadres in the village had sufficient knowledge of balanced nutrition, namely 17 people (81.0\%). Meanwhile, a small proportion of them had less knowledge of balanced nutrition, namely 1 person $(4.8 \%)$. Most of the health cadres in the Sub-districts have sufficient knowledge of balanced nutrition, namely as many as 15 people $(71.4 \%)$. Meanwhile, a small proportion of them had less knowledge of balanced nutrition, namely 2 people $(9.5 \%)$. There is no difference in the level of knowledge of balanced nutrition among health cadres in the village and health cadres in the sub-district with a $p$ value of 0.140 .

\section{References}

Adistie, F., Maryam, N. N. A., \& Lumbantobing, V. B. M. (2017). Pengetahuan Kader Kesehatan Tentang Deteksi Dini Gizi Buruk Pada Balita Di Wilayah Kerja Puskesmas Kecamatan Parigi Kabupaten Pangandaran. Dharmakarya, 6(3).

Badrah, S., Noviasty, R., \& Susanti, R. (2020). Screening of Eating Disorders Risk with Scoff Tool on Adolescents in Samarinda City. Journal La Medihealtico, 1(2), 26-31.

Handayani, S., Soviana, E., Gz, S., Gizi, M., Isnaeni, F. N., \& Gz, S. (2018). Hubungan Tingkat Pengetahuan Tentang Pedoman Umum Gizi Seimbang Dan Asupan Protein Dengan Status Gizi Remaja Putri Di Sma Muhammadiyah 1 Sragen. Thesis, Universitas Muhammadiyah Surakarta.

Hardiyanti, P., \& Susilaningsih, E. Z. (2017). Peran Kader terhadap Peningkatan Gizi Balita Di Desa Banyuraden Sleman Yogyakarta. Thesis, Universitas Muhammadiyah.

Herforth, A., \& Ahmed, S. (2015). The food environment, its effects on dietary consumption, and potential for measurement within agriculture-nutrition interventions. Food Security, 7(3), 505-520.

Kuklinski, J. H., \& Quirk, P. J. (2000). Reconsidering the rational public: Cognition, heuristics, and mass opinion. Elements of reason: Cognition, choice, and the bounds of rationality, 153-182.

Lauglo, J. (2013). Do more knowledgeable adolescents have more rationally based civic attitudes? Analysis of 38 countries. Educational Psychology, 33(3), 262-282.

Miller, L. M. S., \& Cassady, D. L. (2015). The effects of nutrition knowledge on food label use. A review of the literature. Appetite, 92, 207-216.

Shaluhiyah, Z., Kusumawati, A., Indraswari, R., Widjanarko, B., \& Husodo, B. T. Pengetahuan, sikap dan praktik ibu dalam pemberian makanan sehat keluarga di 
Kota Semarang. Jurnal Gizi Indonesia (The Indonesian Journal of Nutrition), 8(2), 92-101.

Yanti, S. V., \& Hasballah, K. M. (2016). Studi Komparatif Kinerja Kader Posyandu. Jurnal Ilmu Keperawatan, 4(2).

Yulisa. (2018). Peran Kader Kesehatan Dalam Penyelenggaraan Kegiatan Posyandu Di Wilayah Kerja Kabupaten Empat Lawang Tahun 2018. Program Studi Ilmu Kesehatan Masyarakat Thesis, Fakultas Kesehatan Masyarakat Universitas Sriwijaya. 